\section{Sweet Corn Hybrid Responses to Thifensulfuron-methyl}

\author{
Nader Soltani, ${ }^{1}$ Peter H. Sikkema, and Darren E. Robinson \\ Ridgetown College, University of Guelph, Ridgetown, Ontario, Canada NOP 2C0
}

Additional index words. Zea mays, sweet corn, sensitivity, tolerance, thifensulfuron-methyl, herbicide injury

\begin{abstract}
Limited information exists on sweet corn (Zea mays) tolerance to postemergence (POST) applications of thifensulfuron-methyl under Ontario growing conditions. Eight sweet corn hybrids were evaluated for tolerance to thifensulfuron-methyl in four field experiments conducted in 2003 and 2004. Thifensulfuron-methyl was applied POST at 6 and $12 \mathrm{~g} \cdot \mathrm{ha}^{-1}$ a.i., the registered and twice the registered rate for use in soybean in Ontario. Sweet corn hybrid responses to thifensulfuron-methyl varied. Delmonte 2038 was the most sensitive to thifensulfuron-methyl and had as much as $92 \%$ visual injury, $76 \%$ height reduction, and $\mathbf{9 8 \%}$ yield reduction compared to the nontreated control. Empire, GH1861, GH2298, and GH2684 hybrids showed visual injury of 53\%, 55\%, 53\%, and $61 \%$, height reduction of $34 \%, 31 \%, 32 \%$, and $26 \%$ and yield reduction of $77 \%, 68 \%$, $68 \%$, and 51\%, respectively. GG214, GH2547, and GSS9299 sweet corn hybrids were not as sensitive to thifensulfuron-methyl. The initial sensitivity observed in these hybrids was minimal and transient with no effect on yield. Although thifensulfuron-methyl is safe for use on some sweet corn hybrids, it has the potential to cause severe crop injury and yield reduction in other hybrids and therefore it should not be recommended for weed management in sweet corn production in Ontario.
\end{abstract}

Sweet corn (Zea mays) production is important to the economy of Ontario where nearly 200,000 t of sweet corn is produced on 17,000 ha. Sweet corn has a farm-gate value of \$22 million, and ranks as the second largest vegetable crop in Ontario in terms of farm-gate value (Mailvaganam, 2004; Ontario Ministry of Agriculture and Food, 2002). Effective weed control is important for the production of sweet corn. The only herbicides registered for postemergence (POST) broadleaf weed control in sweet corn in Ontario are atrazine, bentazon, and bromoxynil [Ontario Ministry of Agriculture and Food (OMAF), 2004]. More research is needed to identify POST herbicides that can more effectively control emerged problem broadleaf weeds in sweet corn production.

Thifensulfuron-methyl is a sulfonylurea herbicide developed for use in soybean ( Glycine $\max$ ) production that inhibits the activity of acetolactate synthase (ALS), an important enzyme necessary for the biosynthesis of branched-chain amino acids isoleucine, leucine, and valine in plants (Vencill, 2002). Thifensulfuron-methyl is applied at very low doses, has low mammalian toxicity, has low potential for groundwater contamination, and controls several broadleaf weeds that occur in Ontario such as common lambsquarters (Chenopdium album L.), redroot pigweed (Amaranthus retroflexus L.), velvetleaf (Abutilon theophrasti Medic.), ladysthumb (Polygonum

\footnotetext{
Received for publication 16 Dec. 2004. Accepted for publication 25 Jan. 2005. The authors would like to acknowledge T. Cowan and K. McNaughton for their expertise and technical assistance in these studies. Funding for this project was provided by the Ontario Processing Vegetable growers and various seed companies that provided seeds.

${ }^{1}$ To whom all correspondence should be addressed; e-mailnsoltani@ridgetownc.uoguelph.ca.
}

Research Station, Exeter, Ont., and Ridgetown College, Ridgetown, Ont., in 2003 and 2004. The soil at Exeter was a Brookston clay loam with $23 \%$ sand, $47 \%$ silt, $30 \%$ clay, $4.0 \%$ organic matter and $\mathrm{pH}$ of 7.7 in 2003, and $34 \%$ sand, $33 \%$ silt, $33 \%$ clay, $3.8 \%$ organic matter, and $\mathrm{pH}$ of 8.0 in 2004 . The soil at Ridgetown was a Watford/Brady loam with $50 \%$ sand, $29 \%$ silt, $21 \%$ clay, $8.2 \%$ organic matter and $\mathrm{pH}$ of 6.8 in 2003 , and $51 \%$ sand, $32 \%$ silt, $17 \%$ clay, $5.5 \%$ organic matter, and $\mathrm{pH}$ of 7.2 in 2004. Seedbed preparation at both locations consisted of fall moldboard plowing followed by two passes with a field cultivator in the spring.

The experiments were arranged in a splitplot design with four replications. The main plots were herbicide rates and subplots were eight sweet corn hybrids. Selection of herbicide rates and spray additives was based on the current maximum use rate in soybean in Ontario. The treatments consisted of a nontreated check and two rates of thifensulfuron-methyl (6 and $12 \mathrm{~g} \cdot \mathrm{ha}^{-1}$ ), the maximum registered use rate and twice the maximum registered use rate in soybean. Thifensulfuron-methyl treatments included $0.1 \%$ and $0.2 \% \mathrm{v} / \mathrm{v}$ nonionic surfactant at 6 and $12 \mathrm{~g} \cdot \mathrm{ha}^{-1}$, respectively (OMAF, 2004). The main plots were $6 \mathrm{~m}$ wide (eight rows) by $10 \mathrm{~m}$ long at Exeter and $6 \times 8 \mathrm{~m}$ at Ridgetown. Each of the eight rows in a plot was planted with a different hybrid.

Sweet corn was planted on 3 June 2003 and 5 June 2004 at Exeter, and 5 June 2003 and 28 May 2004 at Ridgetown. The row spacing was $75 \mathrm{~cm}$ and plants were thinned to a final plant population of 50,000 plants/ha. Eight of the most commonly grown processing sweet corn hybrids in southwestern Ontario were selected. Hybrids included Delmonte 2038, Empire, GG214, GH1861, GH2298, GH2547, GH2684, and GSS9299. Hybrids chosen encompassed a range of endosperm genotypes. A preemergence application of a preformulated mixture of $S$-metolachlor plus atrazine (1:0.8) was applied immediately after planting at $2.16 \mathrm{~kg} \cdot \mathrm{ha}^{-1}$ a.i. in all trials, and plots were maintained weed-free by inter-row cultivation and hand hoeing as required.

Thifensulfuron-methyl was applied to fourto five-leaf stage, $21 \mathrm{~d}$ after planting (DAP) in 2003 and 23 DAP in 2004 at Exeter, and 19 DAP in 2003 and 18DAP in 2004 at Ridgetown. Treatments were applied with a $\mathrm{CO}_{2}$-pressurized backpack sprayer, calibrated to deliver 200 L h ha ${ }^{-1}$ with XR8002VS (Teejet XR8002VS Tip, Spraying Systems Co., Wheaton, Ill.) flat-fan nozzles at 241 and $207 \mathrm{kPa}$ pressure at Exeter and Ridgetown, respectively.

Visual crop injury was rated on a scale of $0 \%$ to $100 \%$ at 7,14 , and $28 \mathrm{~d}$ after treatment (DAT). A rating of $0 \%$ was defined as no visible effect of the herbicide and $100 \%$ was defined as plant death. Visual injury included leaf color changes from green to yellow with a copper tint, leaf distortion and crinkling, growth reduction, and in some sweet corn hybrids total plant necrosis. Height of five randomly selected plants was determined 21 DAT by measuring from the soil surface to the highest point of the corn plant with the leaves extended. The entire 
Table 1. Mean visual injury (\%) of eight sweet corn hybrids 7, 14, and $28 \mathrm{~d}$ after treatment (DAT) with thifensulfuron-methyl postemergence ${ }^{z}$ at 6 and $12 \mathrm{~g} \cdot \mathrm{ha}^{-1}$ a.i. at Exeter and Ridgetown, Ont., in 2003 and 2004.

\begin{tabular}{|c|c|c|c|c|c|c|}
\hline \multirow{4}{*}{$\begin{array}{l}\text { Sweet } \\
\text { corn } \\
\text { hybrid }\end{array}$} & \multicolumn{6}{|c|}{ Mean visual injury (\%) } \\
\hline & \multicolumn{6}{|c|}{ Thifensulfuron-methyl rate $\left(\mathrm{g} \cdot \mathrm{ha}^{-1}\right.$ a.i. $)$} \\
\hline & 6 & 12 & 6 & 12 & 6 & 12 \\
\hline & \multicolumn{2}{|c|}{7 DAT } & \multicolumn{2}{|c|}{$14 \mathrm{DAT}$} & \multicolumn{2}{|c|}{28 DAT } \\
\hline Delmonte 2038 & $33 \mathrm{a}^{\mathrm{y}}$ & $43 \mathrm{a}$ & $69 \mathrm{a}$ & $81 \mathrm{a}$ & $83 \mathrm{a}$ & $92 \mathrm{a}$ \\
\hline Empire & $24 \mathrm{a}$ & $29 \mathrm{~b}$ & $25 \mathrm{bc}$ & $53 \mathrm{~b}$ & $16 \mathrm{~b}$ & $36 \mathrm{bc}$ \\
\hline GG214 & $4 \mathrm{~b}$ & $14 \mathrm{c}$ & $3 \mathrm{~d}$ & $7 \mathrm{c}$ & $2 \mathrm{c}$ & $3 \mathrm{~d}$ \\
\hline GH1861 & $28 \mathrm{a}$ & $39 \mathrm{ab}$ & $23 \mathrm{c}$ & $55 \mathrm{~b}$ & $10 \mathrm{bc}$ & $37 \mathrm{bc}$ \\
\hline $\mathrm{GH} 2298$ & $26 \mathrm{a}$ & $26 \mathrm{~b}$ & $35 \mathrm{~b}$ & $53 \mathrm{~b}$ & $16 \mathrm{~b}$ & $34 \mathrm{c}$ \\
\hline $\mathrm{GH} 2547$ & $2 b$ & $9 \mathrm{c}$ & $2 d$ & $5 \mathrm{c}$ & $1 \mathrm{c}$ & $1 \mathrm{~d}$ \\
\hline $\mathrm{GH} 2684$ & $27 \mathrm{a}$ & $33 a b$ & $35 \mathrm{~b}$ & $61 \mathrm{~b}$ & $21 \mathrm{~b}$ & $49 \mathrm{~b}$ \\
\hline GSS9299 & $5 \mathrm{~b}$ & $15 \mathrm{c}$ & $3 d$ & $8 \mathrm{c}$ & $1 \mathrm{c}$ & $4 d$ \\
\hline SE & 5 & 5 & 7 & 6 & 3 & 3 \\
\hline
\end{tabular}

zThifensulfuron-methyl treatments included $0.1 \%$ and $0.2 \% \mathrm{v} / \mathrm{v}$ nonionic surfactant at 6 and $12 \mathrm{~g} \cdot \mathrm{ha}^{-1}$, respectively.

${ }^{y}$ Results are averaged for both locations and years; means within a column followed by the same letter are not significantly different according to a Fisher's Protected LSD test $(P \leq 0.05)$ on the arcsine (square root) transformed scale; means presented are back-transformed from the arcsine (square root) scale.

row of sweet corn in each plot was harvested by hand at maturity and cob size, marketable (cobs $>5 \mathrm{~cm}$ in diameter) and total yield were determind. As the statistical analyses for total and marketable yields were similar, only total yields are reported.

All data were subjected to analysis of variance (ANOVA). Tests were combined over locations and years and analyzed using the PROC MIXED procedure of SAS (SAS 1999). Variances of percent injury at 7, 14, and 28 DAT, plant height, cob size, and yield were partitioned into the fixed effects of herbicide treatment, hybrids, and herbicide-by-hybrids interaction and into the random effects of test and block (test). Significance of random effects was tested using a $Z$ test of the variance estimate and fixed effects were tested using $\mathrm{F}$ tests. Error assumptions of the variance analyses (random, homogeneous, normal distribution of error) were confirmed using residual plots and the Shapiro-Wilk normality test. To meet the assumptions of the variance analysis, visual injury at 7, 14, and 28 DAT, and cob size data were subjected to an arcsine square root transformation (Bartlett, 1947). Treatment means were separated using Fisher's protected LSD. Means of percent injury were compared on the transformed scale and were converted back to the original scale for presentation of results. Type I error was set at 0.05 for all statistical comparisons.

\section{Results and Discussion}

Visual injury. At 7, 14, and 28 DAT, thifensulfuron-methyl applied POST at 6 and 12 $\mathrm{g} \cdot \mathrm{ha}^{-1}$ caused more injury in Delmonte 2038, Empire, GH1861, GH2298 and GH2684 than in GG214, GH2547, and GSS9299 sweet corn hybrids (Table 1). Visual injury increased with increasing rates of thifensulfuron-methyl.

Visual injury in GG214, GH2547, and GSS9299 was most severe at 7 DAT. However, the injury was transient as indicated by the rating completed 14 and 28 DAT. Visual injury was most severe at 14 DAT in Empire, GH1861, GH2298, and GH2648 hybrids, while Delmonte 2038 showed the highest injury at
28 DAT. Thifensulfuron-methyl POST injuries observed in this study with Delmonte 2038 are consistent with other findings that have shown it to be one of the most sensitive hybrids in Ontario exhibiting as much as $94 \%$ injury when treated with sulfonylurea herbicides (Diebold et al., 2003; O'Sullivan et al., 1998, 2000; O'Sullivan and Sikkema, 2001, 2002). Visual injury generally increased as thifensulfuronmethyl rate was increased from 6 to $12 \mathrm{~g} \cdot \mathrm{ha}^{-1}$. Grey et al. (2000) and O'Sullivan and Sikkema (2001) found similar differential hybrid injury and rate responses with other sulfonylurea herbicides in sweet corn.

Plant height. Sweet corn height data are reported for each hybrid and rate individually, and contrasts were performed comparing height between rates within hybrids (Table 2). The visual injury observed in this study was reflected in the plant height. Thifensulfuron-methyl applied POST at $6 \mathrm{~g} \cdot \mathrm{ha}^{-1}$ reduced plant height by 72 , $20,15,22$, and $16 \%$ in Delmonte 2038, Empire, GH1861, GH2298, and GH2684 hybrids, respectively (Table 2). Thifensulfuron-methyl applied POST at $12 \mathrm{~g} \cdot \mathrm{ha}^{-1}$ reduced sweet corn height by $76 \%, 34 \%, 9 \%, 31 \%, 32 \%, 8 \%, 26 \%$, and $11 \%$ in Delmonte 2038, Empire, GG214, GH1861, GH2298, GH2547, GH2684, and GSS9299 hybrids, respectively (Table 2). Plant heights were generally reduced as the herbicide rate was increased although these results were

Table 2. Height $(\mathrm{cm})$ of eight sweet corn hybrids $21 \mathrm{~d}$ after treatment with thifensulfuron-methyl postemergence at 0,6 , and $12 \mathrm{~g} \cdot \mathrm{ha}^{-1}$ a.i. at Exeter and Ridgetown, Ont., in 2003 and 2004.

\begin{tabular}{|c|c|c|c|c|}
\hline \multirow[b]{3}{*}{ Sweet corn hybrid } & \multicolumn{4}{|c|}{$\mathrm{Ht}(\mathrm{cm})$} \\
\hline & \multicolumn{4}{|c|}{ Thifensulfuron-methyl rate $\left(\mathrm{g} \cdot \mathrm{ha}^{-1}\right.$ a.i. $)$} \\
\hline & 0 & 6 & 12 & SE \\
\hline Delmonte 2038 & $100 a^{y}$ & $28 \mathrm{~b}$ & $24 \mathrm{~b}$ & 5 \\
\hline Empire & $92 \mathrm{a}$ & $74 \mathrm{~b}$ & $58 \mathrm{c}$ & 3 \\
\hline GG214 & 93 a & $90 \mathrm{ab}$ & $85 \mathrm{~b}$ & 2 \\
\hline GH1861 & 93 a & $79 \mathrm{~b}$ & $64 \mathrm{c}$ & 3 \\
\hline GH2298 & $92 \mathrm{a}$ & $72 b$ & $63 \mathrm{c}$ & 3 \\
\hline $\mathrm{GH} 2547$ & $93 \mathrm{a}$ & $89 \mathrm{ab}$ & $86 \mathrm{~b}$ & 2 \\
\hline GH2684 & $98 \mathrm{a}$ & $82 \mathrm{~b}$ & $73 \mathrm{c}$ & 2 \\
\hline GSS9299 & $87 \mathrm{a}$ & $82 \mathrm{ab}$ & $77 \mathrm{~b}$ & 2 \\
\hline
\end{tabular}

${ }^{2}$ Thifensulfuron-methyl treatments included $0.1 \%$ and $0.2 \% \mathrm{v} / \mathrm{v}$ nonionic surfactant at 6 and $12 \mathrm{~g} \cdot \mathrm{ha}^{-1}$, respectively.

${ }^{y}$ Results are averaged for both locations and years; letters represent the statistical comparison using contrasts of the means among thifensulfuron-methyl rates within a variety; means within a row followed by the same letter indicate no significant difference according to a Fisher's protected LSD test $(P \leq 0.05)$. 
Table 3. Cob size (g) of eight sweet corn hybrids treated with thifensulfuron-methyl postemergence ${ }^{\mathrm{z}}$ at 0 , 6 and $12 \mathrm{~g} \cdot \mathrm{ha}^{-1}$ a.i. at Exeter and Ridgetown, Ont., in 2003 and 2004.

\begin{tabular}{lcccr}
\hline & \multicolumn{4}{c}{ Cob size $(\mathrm{g})$} \\
\cline { 2 - 5 } Sweet corn hybrid & 0 & \multicolumn{4}{c}{ Thifensulfuron-methyl rate $\left(\mathrm{g} \cdot \mathrm{ha}^{-1}\right.$ a.i. $)$} & SE \\
\hline Delmonte 2038 & $243 \mathrm{a}^{\mathrm{y}}$ & 6 & $80 \mathrm{c}$ & 14 \\
Empire & $209 \mathrm{a}$ & $172 \mathrm{~b}$ & $124 \mathrm{c}$ & 7 \\
GG214 & $236 \mathrm{a}$ & $225 \mathrm{a}$ & $217 \mathrm{a}$ & 4 \\
GH1861 & $213 \mathrm{a}$ & $164 \mathrm{~b}$ & $131 \mathrm{c}$ & 8 \\
GH2298 & $214 \mathrm{a}$ & $168 \mathrm{~b}$ & $146 \mathrm{c}$ & 6 \\
GH2547 & $232 \mathrm{a}$ & $245 \mathrm{a}$ & $238 \mathrm{a}$ & 5 \\
GH2684 & $229 \mathrm{a}$ & $208 \mathrm{~b}$ & $171 \mathrm{c}$ & 7 \\
GSS9299 & $206 \mathrm{a}$ & $206 \mathrm{a}$ & $199 \mathrm{a}$ & 3 \\
\hline
\end{tabular}

${ }^{2}$ Thifensulfuron-methyl treatments included $0.1 \%$ and $0.2 \% \mathrm{v} / \mathrm{v}$ nonionic surfactant at 6 and $12 \mathrm{~g} \cdot \mathrm{ha}^{-1}$, respectively.

${ }^{y}$ Results are averaged for both locations and years; means have been back transformed to the original scale; letters represent the statistical comparison using contrasts of the means among thifensulfuron-methyl rates within a variety; Means within a row followed by the same letter indicate no significant difference according to a Fisher's protected LSD test $(P \leq 0.05)$.

Table 4. Yield $\left(\mathrm{t} \mathrm{ha}^{-1}\right)$ of eight sweet corn hybrids treated with thifensulfuron-methyl postemergence ${ }^{\mathrm{z}}$ at 0 , 6 and $12 \mathrm{~g} \cdot \mathrm{ha}^{-1}$ a.i. at Exeter and Ridgetown, Ont., in 2003 and 2004.

\begin{tabular}{lcrrr}
\hline & \multicolumn{4}{c}{ Yield $\left(\mathrm{t} \cdot \mathrm{ha}^{-1}\right)$} \\
Sweet corn hybrid & 0 & 6 & 12 & $\mathrm{SE}$ \\
\cline { 2 - 5 } Thifensulfuron-methyl rate $\left(\mathrm{g} \cdot \mathrm{ha}^{-1} \mathrm{a} . \mathrm{i}.\right)$ & 1.3 \\
Delmonte 2038 & $17.0 \mathrm{a}^{\mathrm{y}}$ & $0.3 \mathrm{~b}$ & $0.3 \mathrm{~b}$ & 1.0 \\
Empire & $14.9 \mathrm{a}$ & $8.1 \mathrm{~b}$ & $3.5 \mathrm{c}$ & 0.3 \\
GG214 & $16.5 \mathrm{a}$ & $17.4 \mathrm{a}$ & $16.4 \mathrm{a}$ & 0.9 \\
GH1861 & $16.1 \mathrm{a}$ & $11.0 \mathrm{~b}$ & $5.1 \mathrm{c}$ & 1.1 \\
GH2298 & $16.5 \mathrm{a}$ & $8.1 \mathrm{~b}$ & $5.2 \mathrm{c}$ & 0.9 \\
GH2547 & $20.4 \mathrm{a}$ & $20.4 \mathrm{a}$ & $21.9 \mathrm{a}$ & 1.0 \\
GH2684 & $17.0 \mathrm{a}$ & $13.4 \mathrm{~b}$ & $8.3 \mathrm{c}$ & 0.4 \\
GS59299 & $12.6 \mathrm{a}$ & $13.7 \mathrm{a}$ & $13.4 \mathrm{a}$ & \\
\hline
\end{tabular}

${ }^{2}$ Thifensulfuron-methyl treatments included $0.1 \%$ and $0.2 \% \mathrm{v} / \mathrm{v}$ nonionic surfactant at 6 and $12 \mathrm{~g} \cdot \mathrm{ha}^{-1}$, respectively.

${ }^{y}$ Results are averaged for both locations and years; letters represent the statistical comparison using contrasts of the means among thifensulfuron-methyl rates within a variety; means within a row followed by the same letter indicate no significant difference according to a Fisher's protected LSD test $(P \leq 0.05)$.

\section{Conclusions}

Differential sensitivity of sweet corn hybrids to other sulfonylurea herbicides has been reported in other studies conducted in Ontario(Diebold et al., 2003, 2004; O'Sullivan and Sikkema, 2001, 2002; O'Sullivan et al., $1999,2000,2002)$. In this study, differential sensitivity to postemergence application of thifensulfuron-methyl was observed in sweet corn hybrids. Delmonte 2038 was most sensitive to thifensulfuron-methyl, followed by Empire, GH1861, GH2298, and GH2684. Injury to these hybrids was persistent and resulted in significant yield losses. Generally, crop injury increased as thifensulfuron-methyl rate increased from 6 to $12 \mathrm{~g} \cdot \mathrm{ha}^{-1}$. GG214, GH2547, and GSS9299 were not as sensitive to thifensulfuron-methyl at either rate of application. The initial injury observed in these hybrids was minimal and transient with no detrimental effect on cob size or yield.

This research concludes that thifensulfuronmethyl, although safe for use on some sweet corn hybrids, has the potential to cause severe crop injury and yield reduction in other hybrids. Therefore, thifensulfuron-methyl should not be recommended for weed management in sweet corn in Ontario.

\section{Literature Cited}

Bartlett, M.S. 1947. The use of transformations. Biometrics 3:39-52.

Diebold, S., D. Robinson, J. Zandstra, J. O'Sullivan, and P. Sikkema. 2003. Sweet corn (Zea mays) cultivar sensitivity to AE F130360. Weed Technol. 17:127-132.

Diebold, S., D. Robinson, J.Zandstra, J. O'Sullivan, and P. Sikkema. 2004. Sweet corn (Zea mays) cultivar sensitivity to bentazon. Weed Technol. 18:112-117.

Grey, T.L., D.C. Bridges, P. Raymer, D. Day, and D. Scott NeSmith. 2000. Differential tolerance of fresh market sweet corn cultivars to the herbicides nicosulfuron and primisulfuron. HortScience 35(6):1070-1073.

Mailvaganam, S. 2004. Fresh market sales and sales to processors of specified commercial vegetable crops, Ontario, 2003. 13 Apr. 2004. www.gov. on.ca/OMAFRA/english/stats/hort/vegsale03. html.

Ontario Ministry of Agriculture and Food. 2002. Area, production, and farm value of specified commercial vegetable crops, Ontario, 2002. Ont. Min. Agr. Food. 23 Aug. 2004. http://www. gov.on.ca/OMAFRA/english/stats/hort/index. html .

Ontario Ministry of Agriculture and Food. 2004. Guide to weed control. Ont. Min. Agr. Food (Toronto) Publ. 75.

O'Sullivan, J. and P. Sikkema. 2001. Sweet corn (Zea mays) cultivar sensitivity to CGA 152005 postemergence. Weed Technol. 15:204-207.

O'Sullivan, J. and P. Sikkema. 2002. Sweet corn (Zea mays) cultivar tolerance to primisulfuron. Can. J. Plant Sci. 82:261-264.

O’Sullivan, J., R.J. Thomas, and W.J. Bouw. 1998. Tolerance of sweet corn (Zea mays) cultivars to rimsulfuron. Weed Technol. 12:258-261.

O’Sullivan, J., R.J. Thomas, and W.J. Bouw. 1999. Effect of flumetsulam plus clopyralid soil residues on several vegetable crops and on sweet corn (Zea mays) cultivars grown in rotation. Weed Technol. 13:303-307.

O'Sullivan, J., P. Sikkema, and R.J. Thomas. 2000. Sweet corn (Zea mays) cultivar tolerance to nicosulfuron. Can. J. Plant Sci. 80:419-423.

O’Sullivan, J., J. Zandstra, and P. Sikkema. 2002. Sweet corn (Zea mays) cultivar sensitivity to mesotrione. Weed Technol. 16:421-425.

Robinson, D.K., D.W. Monks, J.R. Schultheis, and A.D. Worsham. 1993. Sweet corn (Zea mays) cultivar tolerance to application timing of nicosulfuron. Weed Technol. 7:840-843.

Robinson, D.K., D.W. Monks, and J.R. Schultheis. 1994. Effect of nicosulfuron applied postemergence and post-directed on sweet corn (Zea mays) tolerance. Weed Technol. 8:630-634.

Sarmah A.K. and J. Sabadie. 2002. Hydrolysis of sulfonylurea herbicides in soils and aqueous solutions: A review. J. Agr. Food Chem. 50:6253-6265.

Schroeder, J. 1998. Cucumber (Cucumis sativus) response to selected foliar and soil applied sulfonylurea herbicides. Weed Technol. 12:595-601.

Stall, W.M. and T.A. Bewick. 1992. Sweet corn cultivars respond differentially to the herbicide nicosulfuron. HortScience 27(2):131-133.

Statistical Analysis Systems. 1999. The SAS System for Windows, Release 8.0. SAS, Cary, N.C.

Van Wychen, L.R., R.G. Harvey, T.M. Anthon, and J.L. Kutil. 1997. Sweet corn hybrid tolerance to ALS-herbicides study. N. Central Weed Sci. Soc. Res. Rpt. 54:7-9.

Vencill, W.K. 2002. Herbicide handbook, p. 88-91. 8th ed. Champaign, Ill. Weed Sci. Soc. Amer. 